BOOKS

\title{
Biography of a complicated, visionary humanitarian
}

Phoenix: The Life of Norman Bethune Roderick Stewart and Sharon Stewart McGill-Queen's University Press; 2011.

$\mathrm{T}$ he aptly titled Phoenix is a remarkable literary resurrection of the spirit of Dr. Norman Bethune. Roderick Stewart's avocation as Bethune's biographer has spanned 42 years, Bethune lived for 49. Phoenix distills decades of interviews, travels and research into a detailed retelling of the Bethune story. The phoenix motif works. Bethune's personality drove cycles of aspiration, failure and resurrection during his lifetime. His legacy has continued to cycle after his death, as one of Canada's most influential, if controversial, figures.

Norman Bethune was born in Gravenhurst, Ontario, received his medical degree from the University of Toronto and practised surgery in Detroit, Michigan and Montréal, Quebec before embarking on his career in international surgery. He established mobile blood banks supporting the republican side during the Spanish Civil War and died leading the medical services of the Eighth Route Army as China struggled against Japanese imperial forces.

As a young man studying art history in London after World War I, Bethune adopted a motto: "To burn always with

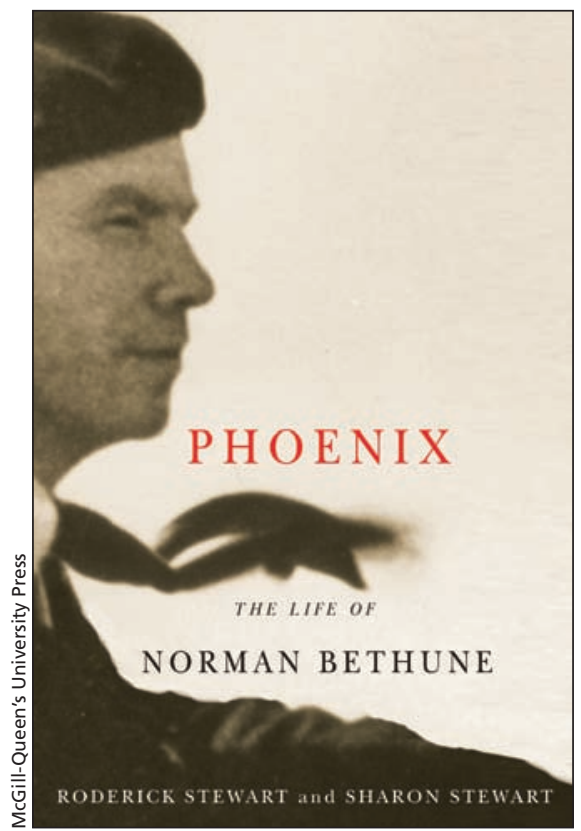

ery from tuberculosis prompted his innovations in apparatus, instruments and surgical approaches, which placed Bethune on the executive of the American Association of Thoracic Surgeons after only two years in practice. But failure soon followed. His surgical colleagues report, "He was erratic as a surgeon. He was erratic in judgment," and "He had a superiority complex, and was entirely amoral." His professional and personal life spiraled downward again - meeting its nadir when he lived in a tent on the grounds of Montréal's Sacre Coeur Hospital, having burned his possessions and his

\section{"He was erratic in judgment," and "He had a superiority complex, and was entirely amoral."}

this hard, gem like flame, to maintain this ecstasy, is success in life." Roderick and Sharon Stewart's interviews with many people who knew Bethune allow them to display all the facets and flaws of his life. To his friend Sorenson, Bethune confided, "[Tuberculosis] has an effect on the brain ... it makes you think faster ... you become more aware of things." Bethune's own recov- apartment in an alcoholic rage. His two marriages (both to Frances Coleman) ended in divorce. Yet, even among the ashes of his self-destruction was the charm reported by his lady friends as "a sort of heightened reality — not just enthusiasm, something more ... vital."

Bethune's early interest in the social determinants of health, his calls for socialized medicine and his initially secret communist party membership set the stage for the next resurrections. The mobile Canadian blood bank supporting the republicans during the Spanish Civil War, followed by the battlefront surgical drama and ultimate martyrdom in China, were steps on a road to redemption that Bethune imposed on himself. He knew when he had failed ("second best," in his narcissistic honesty); as he matured he knew why he had failed. The story of Spanish bombs falling on civilian refugees on the road from Almeira to Malaga, juxtaposed with Bethune's gallivanting in Paris (on donated funds) during his supply trips, resonate with hypocrisy for Bethune and the reader. At the time of his arrival in China he was an ecstatic ascetic devoted to the service of his fellow man, and removed from the temptations that had repeatedly led to his downfall. His 20 month's work in China made him a legend for genuine contributions in the organization and delivery of surgical services along the front. Mao's 700-word eulogy celebrating Bethune's international humanitarianism and selfless devotion made Bethune the best known surgeon in the world. Political fates magnified Bethune's prominence as China and Canada engaged in the 1970s.

According to Stewart and Stewart, Bethune was a communist, a scoundrel, an alcoholic, a womanizer and perhaps a reckless surgeon. Yet he was a visionary, a humanitarian and a champion of the suffering. This biography complements Bethune's writings, collected as The Mind of Norman Bethune, also by Roderick Stewart. Bethune's social vision for health care in Canada has been realized, yet his international humanitarian mission has not. Will posterity fulfill the best Bethune envisioned?

\author{
Andrew Howard MD MSc \\ Director, Office of International Surgery \\ Department of Surgery \\ University of Toronto \\ Toronto, Ont.
}

CMAJ 2012. DOI:10.1503/cmaj.111284 